\title{
THE BIOSYNTHESIS OF GLUCOSAMINE *
}

\author{
By L. F. Leloir and C. E. Cardini \\ Instituto de Investigaciones Bioquimicas, Fundación Campomar \\ Juliain Alvarez 1719, Buenos Aires, Argentina
}

After the isolation of uridine-diphosphateglucose (UDPG) ${ }^{1}$, a very similar compound (UDPG) containing acetylglucosamine instead of glucose was found in yeast ${ }^{2}$. Considering the structural similarity of the two compounds and the coenzymic function of UDPG in the transformation of galactose-Iphosphate into glucose-I-phosphate, it has been considered that UDPG might be involved in the metabolism of hexosamine phosphates. Part of the plan of investigation consisted in a search for enzymes in some organism with a high hexosamine metabolism. Since molds should synthesize large amounts of glucosamine in order to build their cell walls, which contain chitin, experiments have been carried out with Neurospora crassa. While no information on a coenzymic function of UDPG has been obtained several enzymes have been found. Besides a chitinase, the Neurospora extracts were found to contain the enzymes required for the following sequence of reactions: lyze the transformation of this substance into acetylglucosamine-6-phosphate, but no such activity could be detected in rabbit muscle extracts. The interconversion of the acetylglucosamine phosphates is acelerated by glucose-1,6-diphosphate, a fact which bears a resemblance to its action on the mannose ${ }^{3}$ and on the ribose-phosphates ${ }^{4}$. Further studies designed to decide whether the phosphoglucomutase and phosphoacetylglucosaminemutase actions are due to one or two enzymes, and to clarify the mechanism of the stimulation by glucosediphosphate are being carried out.

The synthesis of glucosamine-6-phosphate can also be brought about by a mechanism different from reaction $a$. Thus HARPUR AND QUASTEL $^{5}$ discovered that glucosamine is phosphorylated by ATP in the presence of brain extracts, and from further studies by BROwN ${ }^{6}$ and GRANT AND LONG ${ }^{7}$, it has been concluded that the phosphorylation is catalysed by hexokinase and that the reaction product is
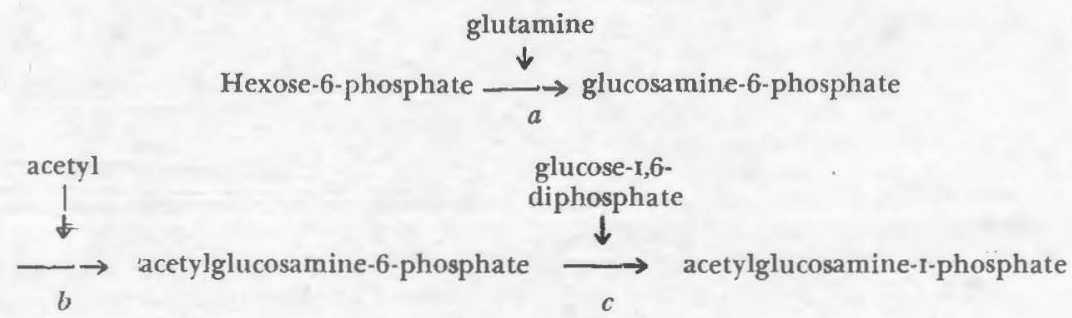

Reaction $a$ and some preliminary studies on reaction $b$ will be dealt with in this paper. As to reaction $c$, it has been detected by using synthetic acetylglucosamine-I-phosphate. Neurospora extracts were found to cata-

* This investigation was supported in part by a research grant (G-3442) from the National Institutes of Health, Public Health Service and by the Rockefeller Foundation. glucosamine-6-phosphate. It is difficult to decide whether this synthesis is a physiological process or simply an unspecific effect:

Similar events have been found to occur with galactosamine. Liver and yeast extracts containing galactokinase were found to phosphorylate galactosamine to a product which appears to be galactosamine-I-phospate ${ }^{8}$. In 
this case, as with glucosamine, the corresponding hexose inhibits the phosphorylation of the hexosamine.

The formation of glucosamine by a process such as reaction $a$ would explain the results of TOPPER AND LIPTON ${ }^{9}$, who found that in Streptococcus the glucosamine formed from glucose- $-{ }^{14} \mathrm{C}$ contained nearly all the label in the I-position.

\section{METHODS}

Analytical. The following methods were used: BLIX10 for glucosamine. Kunitz and MCDonald 11 for protein. Glutamate was estimated with ninhydrin after paper chromatography with phenol 12 . Amide nitrogen by estimation of the ammonia liberated after heating eleven minutes at $100^{\circ}$ in $1 N$ acid 13 . Ammonia by distillation in Conway units 14 and nesslerization.

For the estimation of acetylglucosamine the method of Morgan AND ELSON 15 was slightly modified in order to make it less sensitive to buffers and to reduce the time needed for colour development. The p-dimethylamino benzaldehyde (DAB) reagent was prepared by adding $0.5 \mathrm{~g}$ of DAB to $10 \mathrm{ml}$ of concentrated $\mathrm{HCl}$ and completing to $100 \mathrm{ml}$ with glacial acetic acid. The analytical procedure was as follows: the neutralyzed unknowns and standards containing 0.1-0.5 $\mu$ moles of acetyl glucosamine were taken to 0.5 $\mathrm{ml}$ with water. After adding $0.1 \mathrm{ml}$ of $\mathbf{M}$ sodium carbonate the tubes were heated 5 minutes in a boiling water bath. After cooling $2.5 \mathrm{ml}$ of the DAB reagent were added and mixed immediately with a suitably glass rod. The optical density at $544 \mathrm{~m} \mu$ was measured after 3 to 5 minutes with a Beckman spectrophotometer. The colour increases during 2 minutes and begins to decrease slowly after $3 \mathrm{minu}-$ tes. If the time elapsing between the addition of the DAB reagent and the colorimetric reading is equal in all the samples a good proportionality between concentration of acetylglucosamine and optical density is obtained.

Preparation of the enzyme. A wild type Neurospora crassa E-5297a was grown for three days on "minimal medium" 16 at $30^{\circ}$ under forced aeration. The mycelium was separated by filtration, washed with water, lyophylized and stored over calcium chloride in an evacuated dessiocator at $5^{\circ}$. Extraction of the dried mycelium was effected by homogenizing $0.8 \mathrm{~g}$ in $16 \mathrm{ml}$ of water at $0 \circ$, followed by centrifugation. The supernatant containing about $40 \mathrm{mg}$ of protein per $\mathrm{ml}$ is referred to as crude extract.

Partial purification was carried out as follows: 6.5 $\mathrm{ml}$ of acetone were added to $13 \mathrm{ml}$ of the crude extract at 0 . The inactive precipitate was centrifuged off at 0 . To the supernatant $3.9 \mathrm{ml}$ of acetone were added. The precipitate was separated by centrifugation, washed three times with acetone and dried in an evaciuated desiccator. The yield was about $60 \mathrm{mg}$ of a white powder.

The formation of "glucosamine" was found to' be greater in the presence of 8-hydroxyquinoline, and this fact was attributed to protection of the enzyme from metal inactivation. Therefore, 8-hydroxyquino- line was added to the acetone used in the purification (about $10 \mathrm{mg} \%$ ) and the buffer (pH 6.5) used for dissolving the enzyme was saturated with 8-hydroxyquinoline.

The enzyme in "solution was found to lose activity in a few hours at $5^{\circ}$ and in a few days at -109 .

The ratio: $\mu$ moles of glucosamine formed/mg protein per hour, was about 0.04 for the crude enzyme and usually about 0.3 for the acetone fractionated enzyme.

Acetylation experiments. The enzyme preparation used was a crude extract which had been dialyzed about two hours against running water. The enzyme system was similar to that used by KAPLAN AND LIPMANN 17. The CoA solution was an aqueous extract of rat liver. In every case controls in which the reaction was stopped at time $=o$ were run simultaneously. The reaction was stopped by immersing the tubes in boiling water followed by centrifugation.

Acetylglucosamine was estimated in the supernatant as described above. In some cases the phosphoric esters were precipitated by adding $0.3 \mathrm{ml}$ of $5 \%$ zinc sulphate and $0.3 \mathrm{~N}$ barium hydroxide until the suspension gave a rose colour with phenolphthalein.

The formation of "glucosamine". Incubation of hexose-6-phosphate with glutamine and the enzyme gave rise to an increase in the glutamine content. As shown in Fig. 1, hardly any increase took place when glutamine or hexose-6-phosphate were omitted.

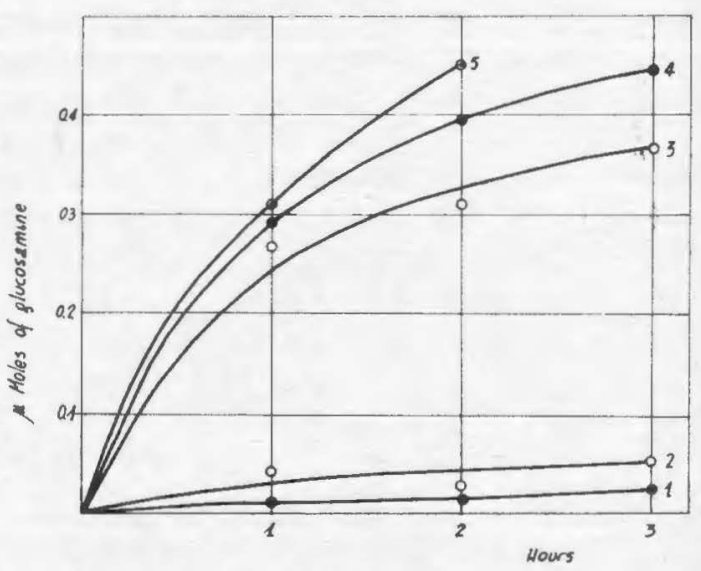

Fig. 1. - The formation of glucosamine. Incubation at $30^{\circ}$ of $\mathrm{I} \mathrm{mg} \mathrm{of} \mathrm{purified} \mathrm{enzyme} \mathrm{and} 0.05 \mathrm{ml}$ of trishydroxymethylaminoethane acetate buffer of $\mathrm{pH}$ 6.4 with substrates. Total volume, $0.2 \mathrm{ml}$.

Curve 1, o $\mu$ moles of hexose-6-phosphate

$+2 \mu$ moles of glutamine

Curve 2, 2 moles of hexose-6-phosphate

$+o \mu$ moles of glutamine

Curve 3, $1 \mu$ moles of hexose-6-phosphate

$+5 \mu$ moles of glutamine

Curve 4, $4 \mu$ moles of hexose-6-phosphate

$+2 \mu$ moles of glutamine

Curve 5, $4 \mu$ moles of hexose-6-phosphate

$+5 \mu$ moles of glutamine 
The results of an analysis of the chemical changes occurring during the reaction appear in Table 1. The increase in "glucosamine" was approximately equal to the decrease in amide nitrogen of glutamine and to the increase in glutamate. There occurred also a small increase in ammonia in the complete system as well as in the controls without glutamine.

An experiment carried out at different temperatures appears in Table II. At $37^{\circ}$ glucosamine formation was faster than at $30^{\circ}$ in the beginning, but slower afterwards.

In many experiments it was observed that the enzyme solutions became rapidly inactivated at room temperature. On the other hand, in the experiments of Fig. I the enzyme in the presence of the substrates was still active after 3 hours at $30^{\circ}$. An experiment was therefore carried out in order to ascertain which of the substrates exerted a stabilizing action. Samples of the enzyme were preincubated 30 minutes at $30^{\circ}$ with or without substrate, and then the enzyme system was completed.

The glucosamine formed in one hour was as follows (the amount formed during prein- cubation was subtracted):

Preincubated without substrate

Preincubated with glutamine

0.76

Preincubated with hexose-6-phosphate $\quad 0.70$

No preincubation

0.80

Thus both substrates, and specially glutamine, exerted a considerable stabilizing action.

Specificity. Glucose-6-phosphate could be replaced by fructose-6-phosphate, but not by any of the following substances: maltose, glucose, mannose, fructose, fructose-I,6-diphosphate, glucose-1,6-diphosphate, $\alpha$-galactose-1. phosphate, fructose-1-phosphate, glucose-2 phosphate, xylose-5-phosphate, dihydroxyacetone or glyceraldehyde.

The enzyme preparation was found to contain considerable amounts of the enzyme which catalyzes the interconversion of fructose-6-phosphate into glucose-6-phosphate. The activity of this isomerase was estimated by measuring the disappearance of fructose phosphate with RoE's ${ }^{18}$ method. It was found that under the conditions used for measuring glucosamine formation the equilibrium values for the glucose-fructose esters was attained in about 5 minutes. Therefore, it has not been passible to decide whether the reactant:

TABLE I

Balance experiment

The aliquots of the complete system taken for analysis contained: 1,3 $\mu$ moles of glutamine, $1.3 \mu$ moles of glucose-6-phosphate and $0.6 \mathrm{mg}$ of purified enzyme and citrate buffer. pH 6.4. Total volume, $0.1 \mathrm{ml}$. Incubated 3 hours ast $30^{\circ}$.

\begin{tabular}{|c|c|c|c|c|}
\hline & $\begin{array}{l}\text { "glucosa- } \\
\text { mine" }\end{array}$ & $\triangle$ amnide & $\mathrm{NH}_{3}$ & glutamate \\
\hline Complete system & 0.42 & -0.39 & 0.17 & 0.36 \\
\hline No glutamine & 0.03 & -0.07 & 0.14 & 0.08 \\
\hline No hexose-6-phosphate & 0.03 & -0.04 & 022 & 0.10 \\
\hline
\end{tabular}

TABLE II

Formation of "glucosamine" at different temperatures Complete system as in Table I. Results in $\mu$ moles.

\begin{tabular}{ccccc}
\hline & \multicolumn{5}{c}{ Time of incubation } & (mintutes) \\
\cline { 2 - 5 } Temperature & 30 & 60 & 120 & 180 \\
\hline $24^{\circ}$ & 0.08 & 0.20 & - & 0.46 \\
$30^{\circ}$ & 0.13 & 0.24 & 0.40 & 0.52 \\
$37^{\circ}$ & 0.16 & 0.20 & 0.34 & 0.40 \\
\hline
\end{tabular}


is glucose-6-phosphate or fructose-6-phosphate.

"Glucosamine" was formed when glucose-Iphosphate was used instead of hexose-6 phosphate with the crude enzyme, but not with the purified preparations. Under the conditions of the test and with the purified enzyme the phosphoglucomutase activity was very weak.

The substances which were tested with negative results as possible substitutes for glutamine were the following: asparagine, glutamic and aspartic acids, arginine, putrescine, urea, ammonium acetate, alanine, glycine, butyramide, serine, cysteine, lysine, ornithine, valine, leucine and citrulline. Pairs such as ammonium salts with ATP, asparagine and glutamate, etc., also gave negative results.

$p H$ optimum. As shown in Fig. 2, the reaction has a sharp $\mathrm{pH}$ optimum at $\mathrm{pH}$ 6.4-6.8.

Study of the "glucosamine" ester. $100 \mu \mathrm{mo}$ les each of glutamine and hexosemonophosphate plus $50 \mathrm{mg}$ of enzyme in $10 \mathrm{ml}$ of 0.025 $M$ tris-acetate buffler ( $\mathrm{pH}$ 6.4) were incubated 3 hours at $30^{\circ}$. The proteins were removed by heat coagulation. Barium acetate was added to the clear liquid and the $\mathrm{pH}$ was adjusted to 8 . The mixture was centrifuged and the precipitate was washed twice

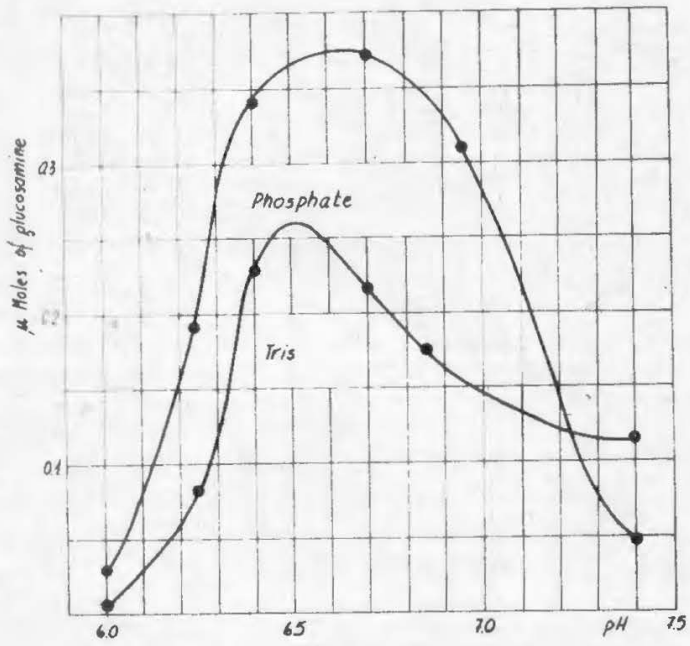

Fig. 2. $-\mathrm{pH}$ optimum curve. System composed of $2 \mu$ moles each of hexose-6-phosphate plus $1 \mathrm{mg}$ of enzyme and $0.1 \mathrm{ml}$ of $0.1 \mathrm{M}$ phosphate or trishydroxymethylaminoethane acetate buffers. Incubated 2 hours at $30^{\circ}$. The $\mathrm{pH}$ was determined on aliquots with a glass electrode. with $1 \mathrm{ml}$ of water. Three volumes of ethanol were added to the pooled supernatants. The precipitate was redissolved in $10 \mathrm{ml}$ of water, a small preçipitate centrifuged off and three volumes of ethanol were again added. The precipitate was then dried with ethanol and ether. Yield, $20 \mathrm{mg}$. These were dissolved in $2 \mathrm{ml}$ of water. The solution contained $41 \mu$ moles of total phosphate, $36 \mu$ moles of reducing substance calculated as glucose, and $5.5 \mu$ moles of "glucosamine". Direct paper chromatography of this ester mixture in different solvents gave irregular results, so that it was decided to remove the phosphate group.

$0.5 \mathrm{ml}$ of the above solution was made $0.01 \mathrm{M}$ in respect to $\mathrm{Mg}^{+2}$, and $10 \mathrm{mg}$ of a kidney phosphatase preparation and a drop of toluene were added. After 16 hours at $37^{\circ}$, about $70 \%$ of the phosphate was hydrolysed. The mixture was then deproteinized with trichloroacetic acid, washed with ether and used for paper chromatography. A sample of glucosamine-6-phosphate was run simultaneously. One of the solvents used was a mixture of ethyl acetate-pyridine-ammonia ${ }^{2}$ with which it is possible to separate glucosamine from galactosamine. The other solvent was phenol-water ${ }^{19}$ with ammonia. Phenol without ammonia was used with paper which had been immersed in $0.1 M$ zinc sulphate and dried in air. This procedure was based on a previous observation which disclosed that zinc ions greatly retard the migration of hexosamines but only have a small influence on others sugars. It was also observed that with an alkaline solvent there was no retardation by zinc ions.

The results of the chromatography are shown in Table III. The ex-ester sugar mixture gave spots which migrated like glucose and glucosamine. The position of the substances was revealed with the aniline phthalate reagent ${ }^{20}$, and that of hexosamines was checked with the modified ELSON AND MORGAN reagent ${ }^{19}$. Besides glucose and glucosamine, the ex-ester mixture contained small amounts of another hexose which migrated like mannose. In some cases a very faint spot with the $R$-glucose value of fructose was observed. The presence of these sugars is not surprising since the sample of hexose-6-phosphate used was obtained by the action of yeast enzymes. 
TABLE III

Paper chromatography of the "glucosamine" ester after treatment with phosphatase

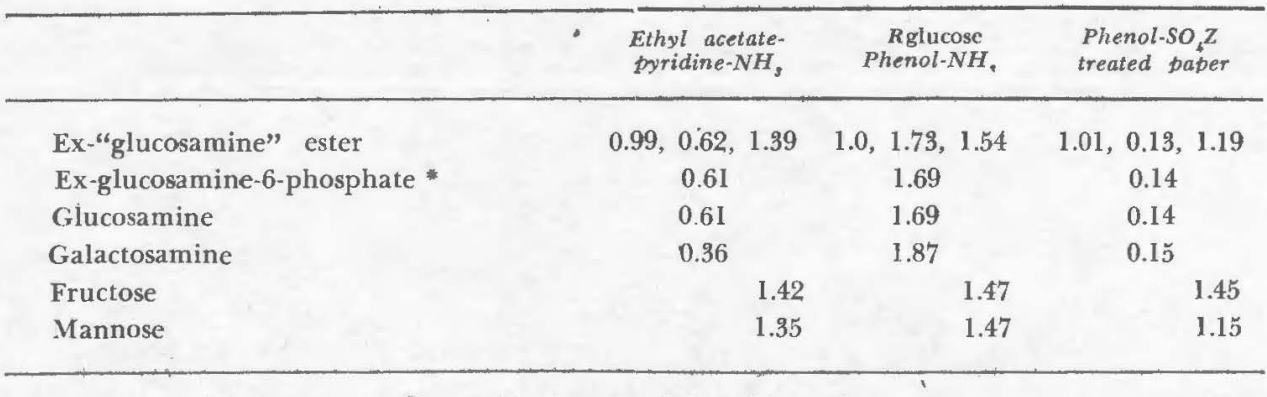

* Prepared from glucosamine with ATP and hexokinase 6.

Acetylation. As shown in Table IV, Neurospora extracts, when suitably supplemented are able to bring about the acetylation of glucosamine. These extracts are also able to catalyze the phosphorylation of glucosamine (Table V) and contain phosphatase. The result of the action of this set of enzymes is that starting with free glucosamine or with glucosamine-6-phosphate, the reaction pro- ducts are similar. Most of the acetylglucosamine appears free and a part precipitates with zinc suplphate-barium hydroxide as would acetylgluçosamine phosphate (Table VI). If acetylglucosamine phosphate was formed, it could not have arisen by phosphorylation of acetylglucosamine, since this process is not catalyzed by the extracts (Table V). Therefore, it seems logical to conclude that gluco-

TABLE IV

$\rightarrow$

The acetylation of glucosamine

Complete system: $2 \mu$ moles of glucosamine, $4 \mu$ moles of ATP, $0.065 \mathrm{ml}$ of $1 \mathrm{M}$ sodium acetate, $0.05 \mathrm{ml}$ of $0.1 \mathrm{M}$ cysteine, $0.05 \mathrm{ml}$ of $0.2 \mathrm{M}$ sodium citrate of $\mathrm{pH} 7,0.1 \mathrm{ml}$ of CoA solution, $0.05 \mathrm{ml}$ of $0.1 \mathrm{M}$ magnesium chloride and $0.2 \mathrm{ml}$ of crude dialyzed enzyme. Final volume, $0.7 \mathrm{ml}$. Incubation 2 hours at $37^{\circ}$.

moles of acetylglucosamine formed

$\begin{array}{ll}\text { Complete system } & 0.38 \\ \text { No glucosamine } & 0.025 \\ \text { No CoA } & 0.075 \\ \text { No ATP } & 0.025 \\ \text { No } \mathrm{Mg}++ & 0.070\end{array}$

TABLE V

The phosphorylation of glucosamine

Complete system as in Table III, but without CoA. The difference in glucosamine or acetylglucosamine content between samples incubated with and without ATP was considered to be due to phosphorylation. The estimations were carried out after precipitation of proteins and phosphoric esters with zinc sulphate and barium hydroxide.

\begin{tabular}{|c|c|c|}
\hline \multirow{2}{*}{ Substrate } & \multicolumn{2}{|c|}{$\Perp$ moles of substrate phosphorylated } \\
\hline & No $\mathrm{Mg}++$ & With $\mathrm{Mg}++$ \\
\hline Glucosamine & 0.8 & 1.80 \\
\hline Acetylglucosamine & 0 & 0 \\
\hline
\end{tabular}


T.ABI.E VI

The acelylation of glurosamine phospluate

Complete system as in Table JII. The acetylglucosamine content of the supernatant. after zinc sulphate-barium hydroxide precipitation was considerel as frec acetylglucosamine.

\begin{tabular}{|c|c|c|c|}
\hline Suhstrate & $\begin{array}{l}\text { of incubation } \\
\text { (minutes) }\end{array}$ & $\begin{array}{l}\text { umoles of } \\
\text { Total }\end{array}$ & $\begin{array}{c}\text { acetylglurosamine formed } \\
\text { Free }\end{array}$ \\
\hline \multirow[t]{3}{*}{ Ciluscosamine } & 30 & 0.26 & 0.18 \\
\hline & (i) & 0.40 & 0.28 \\
\hline & 120 & 0.38 & 0.25 \\
\hline (ilucosamine-(i-plossplyate & 120 & 0.60 & 0.49 \\
\hline
\end{tabular}

I.IBI.E. V'II

The acelylation of the "glucosamine" ester

The "glucosaminc" cster was obtained by incubation during 3 hours at $30^{\text {" of }} 2$ monole, eath of glutamine and hexose-6-phosphate with the purified enzyme. The controls containe: the same substances plus glucosamine $(0.5 \mu$ moles $)$ or glucosamine-6-phosphate (1 $\mu$ mol). and the reaction was stopped at $t=0$. The acetylating system described in Table III wat, then added.

\begin{tabular}{lc}
\hline & $\mu$ moles of acelylglucosamine formed \\
\hline "Colucosaminc" cester & 0.21 \\
Control with glucosumine & 0.20 \\
control with glucosamine-(j-phosphate & 0.31 \\
\hline
\end{tabular}

samine-ti-phosphate can be acetylated directly to acetylglucosamine phosphate.

Table VII shows the results of the action of the acetylating system on the "glucosamine" ester formed from hexose phosphate and glutamine. This substance gave rise to acetylglucosamine, as did glucosamine or glucosamine-6i-phosphate.

\section{DISCIISSION}

The substance formed from hexose-6-phosphate and glutamine gives the ELson and MORGAN and DISCHE 21 reactions for hexosamines. It can be prepared as the barium salt achixed with hexosemonophosphates. It behaves like glucosamine-6-phosphate when incubated with the acetylating system of Neurospora, and after dephosphorylation with phosphatase glucosamine can be idlentified by paper chromatography with selerted solvents.

All this is consiclered as evidence proving that the product is glucosamine phosphate. The ester gives positive reactions for hexosamines, so that a l-ester can be excluded, and since a migration of the phosphate cluring the reaction appears unlikely, the product should be glucosamine-6-phosphate.

No eviclence for the necessity of a colactor for the lormation of glucosamine phosphate was obtained. Thus, no stimulation was obtained by the addition of different ions, ATP, pyricloxal phosphate, LIDPAG, etc. The mechanism of the reaction cannot be discussed until it is decicled whether the reactant is iructose-6- or glucose-6-phosphate, In order to settle this point it will be necessary to obtain enzyme preparations free from isomerase.

Further investigation will also be necessary in order to decide whether the acetylation step takes place on free glucosamine. on glucosamime-(6)-phosphate or on both. In commection with this point, it may be mentioned that Chor and Soodak 22 extrated an enzme lrom pigeon liver which catalyzed the atcetylation of free glucosamine and galactosamine, but that the corresponding phosphates were not tested. 


\section{SUMMARY}

A partially purified enzyme has been prepared from Neurospora crassa which catalyzes the formation of glucosamine phosphate from hexose-6-phosphate and glutamine. The glucosamine phosphate was identified by colour reactions, by dephosphorylation and paper chromatography and by its behaviour towards an acetylating system.

Quantitative analysis of amide nitrogen, glutamate, and hexosamine agreed with the following equation:

Hexose-6-phosphate + glutamine $\rightarrow$ glucosamine-6-phosphate + glutamate.

Crude Neurospora extracts were found to phosphorylate. glucosamine in the presence of ATP anil, when suitably supplemented, to acetylate glucosamine or glucosamine phosphate.

\section{RESSUME}

Lcs auteurs out préparé et partiellement purifié à partir de Neurospora crassa, un enzyme qui cata. lyse la formation de glucosamine phosphate à partir d'hexose-6-phosphate et de glutamine. Le glucosaminephosphate a été identifié par ses réaction colorées, par la déphosphorylation, par la chromatographie sux papier et par son comportement en présence d'un système acétylant.

\section{REFERENGES}

1. C. E. Cardini, A. C. Paladini, R. Caputto and L. F, LeloIr, Nature, 165 (1950) 191; R. CAPUtro, L. F. Leloir, C. E. Cardini and A. C. PalaDINI, J. Biol. Chem., 184 (1950) 333.

2. E. Cabib, L. F. Leioir and C. E. Cardini, Ciencia e invest. (Buenos Aires), 8 (1952) 469; $J$. Biol. Chem. (in press).

3. L, F. Lelotr, in Phosphorus Metabolism, A Symposium on the Role of Phosphorus in the Meiabolism of Plants and Animals, Johns Hopkins Press; Baltimore, 1951, p. 67.

4. H. Klenow and B. LaRsen, Arch. Biochem. Biophys., 37 (1952) 488.

5. R. P. Harpur and J. H. Quastel, Nature, 164 (1949) 693.

6. D. H. Brown, Biochim. Biophys. Acta, 7 (1951) 487.

7. P. T. Grant and C. Long, Biochem. J., 50 (1952) $\mathrm{xx}$

8. C. F. Cardini and L. F. Leloir, unpublished results.

9. Y. J. Topper and M. M. Lipton, Federation Proc., 11 (1952) 299.
L'analyse quantitative de l'azote amidé, du gluta. mate et de l'hexosamine est en accord avec l'équition suivante:

Hexose-6-phosphate + glutamate $\rightarrow$ Glucosamine-6-phosphate + glutamate.

Les extraits bruts de Neurospora phosphorylent la glucosamine en présence d'ATP et écatylent la glu. cosamine et le glucosaminephosphate, quand on les supplémente convenablement.

\section{ZUSAMMENFASSUNG}

Ein teilweise gereinigtes Enzym, das die Bildung von Glucosaminphosphat aus Hexose-6.phosphat und Glutamin katalysiert, wurde aus Neurospora crassa dargestellt. Das Glucosaminphosphat wurde durch Farbreaktionen, Desphosphorylierung und Papierchromatographie und durch sein Verhalten gegenüber einem acetylierten System identifiziert.

Die quantitative Analyse von Amidstickstoff, glutaminsaurem Salz und Hexosamin stimmte mit der folgenden Gleichung überein:

Hexose-6-phosphat + Glutamin $\rightarrow$ GlucosaminG-phosphat + Glutaminsaures Salz.

Es wurde gefunden, dass rohe Neurospora-extrakte Glucosamin in Gegenwart von ATP phosphorylieren und, wenn sie geeignet ergänzt werden, Glucosamin oder Glucosaminphosphat acetylieren.
10. G. Buix, Acta Chem. Scand., 2 (1948) 467.

11. M. Kunitz And M. McDonald, J. Gen. Physiol., 29 (1945) 411.

12. J. Awapara. J. Biol. Chem., 178 (1949) 113.

13. J. F. Speck, J. Biol. Chemp, 179 (1949) 1387.

14. E. J. Conway, Micro-Diffusion Analysis and Vo. lumetric Error, Crosby Lockwood \& Son Ltd., London, 1939.

15. W. T. T. Morgan And L. A. Elson, Biochem. J., 28 (1934) 988.

16. G. W. Beadle and E. L. Tatum, Am. J. Botany, 32 (1945) 678.

17. N. O. Kaplan and F. Lipmann, J. Biol. Chem., 174 (1948) 37.

18. J. H. RoE, J. Biol. Chem., 107 (1934) 15.

19. S. M. Partridge, Biochem. J. 42 (1948) 238.

20. S. M. Partridge, Nature, 164 (1949) 443.

21. Z. Dische and E. Borenfreund, J. Biol. Chem., 181 (1950) 517.

22. T. Chou And M. Soodak, J. Biol. Chem., 196 (1952) 105. 